\title{
Особенности клеточной гибели моноцитов больных атопической бронхиальной астмой
}

\author{
() Б.Р. Ибрагимов, Ю.В. Скибо, З.И. Абрамова \\ Казанский (Приволжский) федеральный университет \\ Россия, Республика Татарстан, 420008 г. Казань, улица Кремлевская, 18
}

\section{Email: ibragimov94@inbox.ru}

Для оценки характера программируемой клеточной гибели использовали метод трансмиссионной электронной микроскопии и установили существенные морфологические отличия - у больных тяжелой формой атопической бронхиальной астмой в основном встречаются макрофраги с признаками развития аутофагии.

Ключевые слова: апоптоз, каноническая аутофагия, Lap-ассоицированный фагоцитоз, макрофраги, атопическая бронхиальная астма.

Многолетние исследования специалистов показали, что, в иммунопатогенезе атопической бронхиальной астмы ведущую роль играют нарушения регуляции как гуморальных, так и клеточных реакций иммунной системы на специфический антиген. Однако единого взгляда на конкретные механизмы развития дисрегуляции в иммунной системе при атопической астме до сих пор не существует. За прошедшие десятилетия в роли общепринятых выступали теории, признающие ведущую роль: нарушений регуляции В-лимфоцитов по Адо А.Д. [1]; нарушений супрессорной функции лимфоцитов [2]; нарушений баланса Th1 и Th2-лимфоцитов [3] . Но предполагалось, что в патогенезе нарушений иммунной системы при АБА важную роль играют и другие, еще не изученные подробно процессы. Например, интересно проследить характер активационного процесса в связи с количественными изменениями иммунокомпетентных клеток. Поддержание гомеостаза, в том числе и клеточного, является одним из основных свойств всего живого. Оно достигается сбалансированностью процессов клеточной пролиферации и клеточной гибели (апоптоза).

Изучению пролиферации лимфоцитов при АБА посвящены многие исследования. Но в последние два десятилетие обращают внимание на роль нарушения клиренса продуктов апоптоза при аллергических заболеваниях, в том числе при атопической бронхиальной астме [4]. Таким образом, используя представления об этом процессе, как считают исследователи, можно объяснить некоторые патогенетические аспекты развития аллергического процесса.

Аутофагия - эволюционно консервативный путь, создающий круговорота органелл и белков с помощью лизосомной обработки. Во время аутофагии образованные структуры с двойной мембраной, называемые аутофагосомами, инкапсулируют цитоплазматический материал, такой как дисфункциональные или поврежденные органеллы, белки или продукты апоптоза. Существует все больше доказательств того, что аутофагия также может влиять на патогенез и / или прогрессирование многих заболеваний человека [4], включая иммунные расстройства (астму) и хроническую обструктивную болезнь легких (ХОБЛ). Распознавание и удаление мертвых клеток - процесс, который должен протекать эффективно, без протекания аутоиммунных или воспалительных процессов [5]. Процесс аутофрагии для утилизации поврежденных клеток может осу- 
Цель работы - оценка морфологических особенностей моноцитов больных легкой и тяжелой формами атопической бронхиальной астмой.

Моноциты - клетки врожденной иммунной системы, обладающие способностью фрагоцитировать, продуцировать цитокины и представлять антигены. Для изучения биологических функций моноцитов в качестве диагностических и исследовательских целей в условиях культивирования in vitro стоит необходимость в получении высокого качества и количества исследуемых клеток. Мембранный белок CD 14 экспрессируется преимущественно на моноцитарных клетках, и служит основным маркером при определении моноцитов из общей фрракции мононуклеарных клеток. Существует метод выделения моноцитов из периферической крови на градиенте плотности Фиколла, однако, при разделении в стандартном градиенте, лимфоциты и моноциты имеют близкие характеристики, в связи с чем, получить обогащенную фрракцию моноцитов затруднительно. В нашей работе модифицирована методика выделения с достаточно высоким выходом моноцитов из общей фракции крови, на основе центрифугирования в оптимизированном градиенте плотности Перколла. Разделение двух типов клеток возможно благодаря разной чувствительности к осмотическому давлению. Лимфоциты более чувствительны к увеличению осмолярности, чем моноциты. Полученные данные показали, что чем выше осмолярность, тем выше чистота, но тем ниже выход моноцитов. Оптимальными условиями для выделения моноцитов из фракции мононуклеарных клеток, при которых происходит очистка и от тромбоцитов и от мертвых клеток, обладает $46 \%$ ISOосмотический раствор Перколла. Использование ISO-осмотического градиента плотности Перколла позволило получить обогащенную фракцию моноцитов. Для снижения токсичности реагента Перколла и повышения жизнеспособности клеток, при разделении использовалась питательная среда RPMI с добавлением $10 \%$ эмбриональной телячьей сыворотки с сохранением 46\% ISO-осмотической плотности. Питательная среда добавлялась к мононуклеарным клеткам, а так же в раствор Перколла, на который наслаивался образец. Для лучшей визуализации разделения фраз использовалась среда RPMI с феноловым красным и без фенолового красного.

Чистота и извлечение моноцитов составила около $70 \%$, наличие белка CD 14, показанное методом проточной цитометрии подтвердило, что полученная фракция содержит моноциты (рис. 1).

При анализе физиологического состояния фракции моноцитов мы показали (рис.2), что во фрракции моноцитов от здоровых доноров часть клеток находится в состоянии апоптоза (Q1,Q2), во фрракции моноцитов больных тяжелой формой астмы увеличивается процент некротических клеток (Q3). 


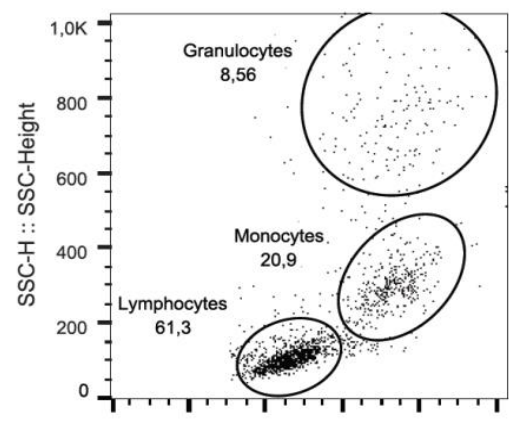

A.

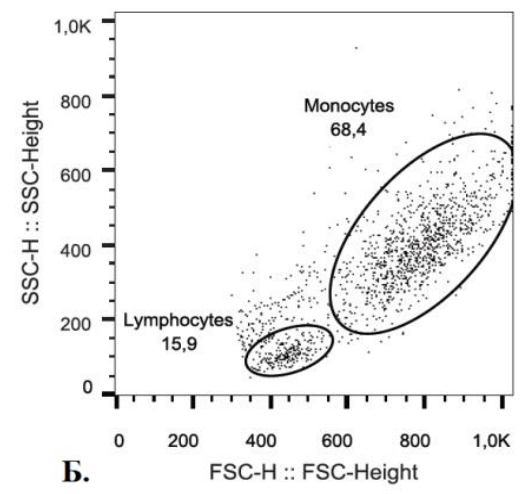

Б.

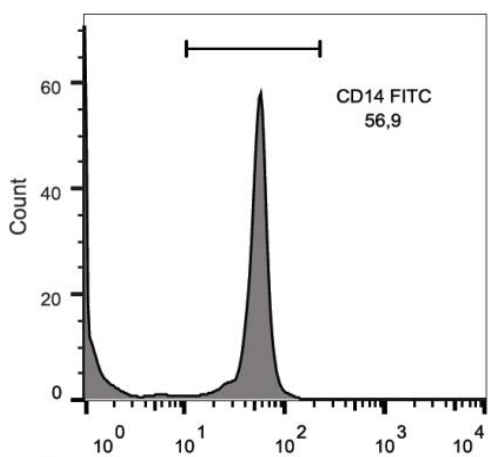

B.

Рис. 1. Этапы выделения моноцитов: А - состав мононуклеарных клеток периферической крови, выделенных на градиенте плотности Фиколла ( моноцитов 20,9 \%), Б - состав мононуклеарных клеток периферической крови, после очистки на градиенте плотности перколла $(58,4 \%)$; В - Субпопуляция моноцитов, «окрашенная» CD14. Репрезентативный результат.

A

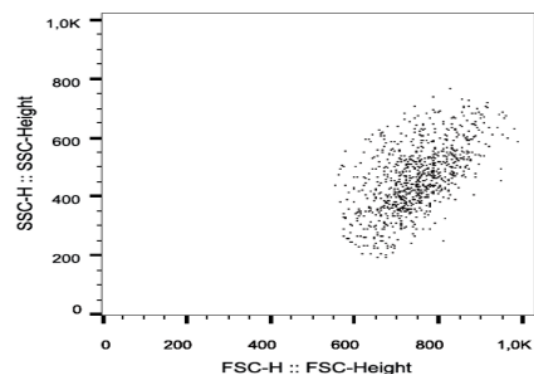

B

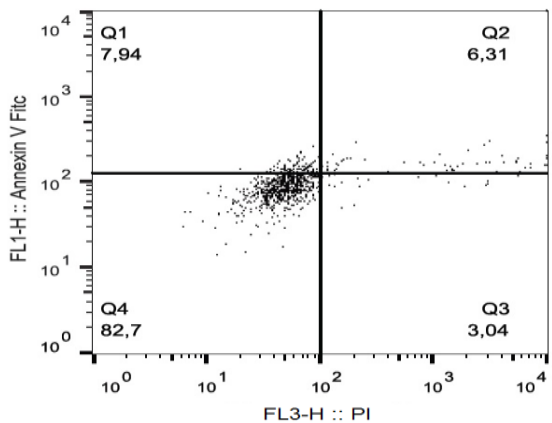

B1
Б
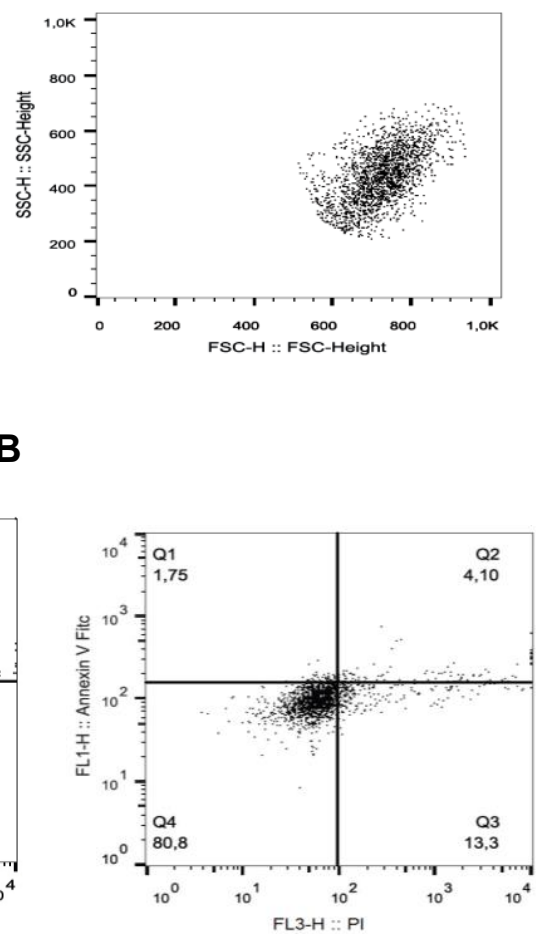

B2

Рис.2. Отдельная популяция моноцитов (2000 событий): А - здоровых доноров и Б больных тяжелой формой астмы. (В)- Оценка уровня апоптоза и некроза методом проточной цитометрии в моноцитах здоровых доноров ( В1) и больных тяжелой формой астмы (B2). Окрашивание Annexin и РІ. Репрезентативный результат.

Для оценки аутофагии в моноцитах мы использовали метод трансмиссионной электронной микроскопии (Рис.3). 
Al

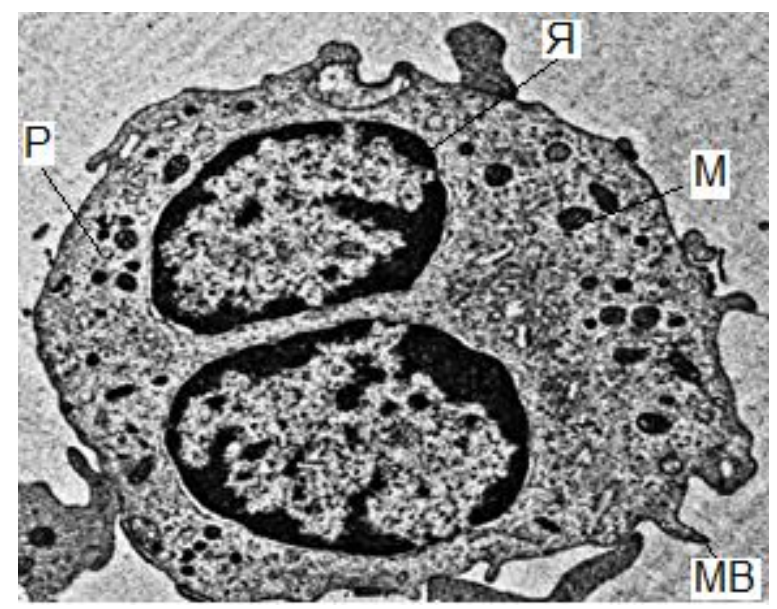

БII

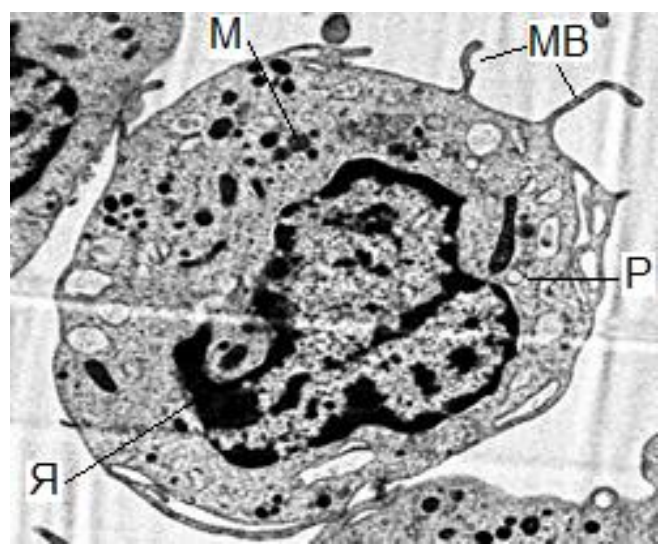

Изменение структуры моноцита в зависимости от тяжести атопической астмы; А.I - моноцит здоровых доноров: Б.ІІ - диффреренцирующийся макрофраг больных тяжелой фрормой астмы. Я - ядро, Р - рибосомы, МВ - микроворсинки и складк, Ммитохондрии.

B

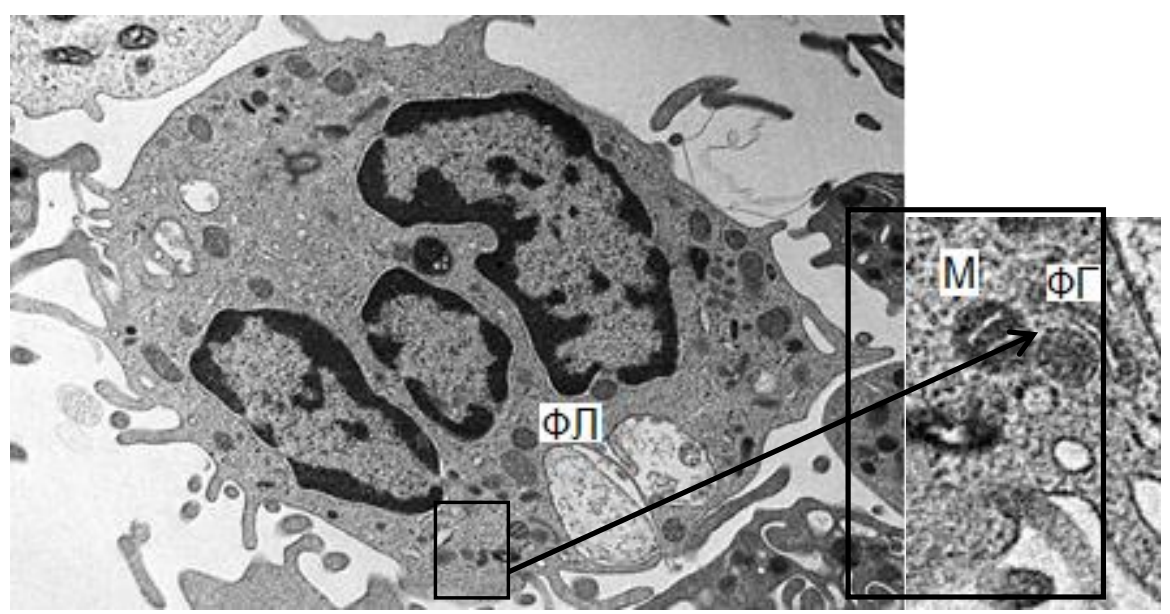

Зрелый макрофраг фракции больных тяжелой формой астмы: ФЛ-фраголизосома; ФГфагофор-фрормирующаяся двойная мембрана аутофагосомы, М - митохондрии 


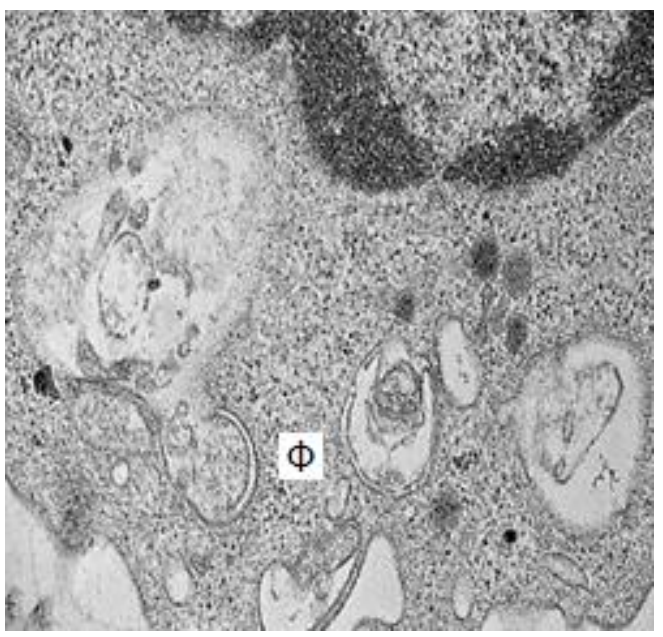

Г.I

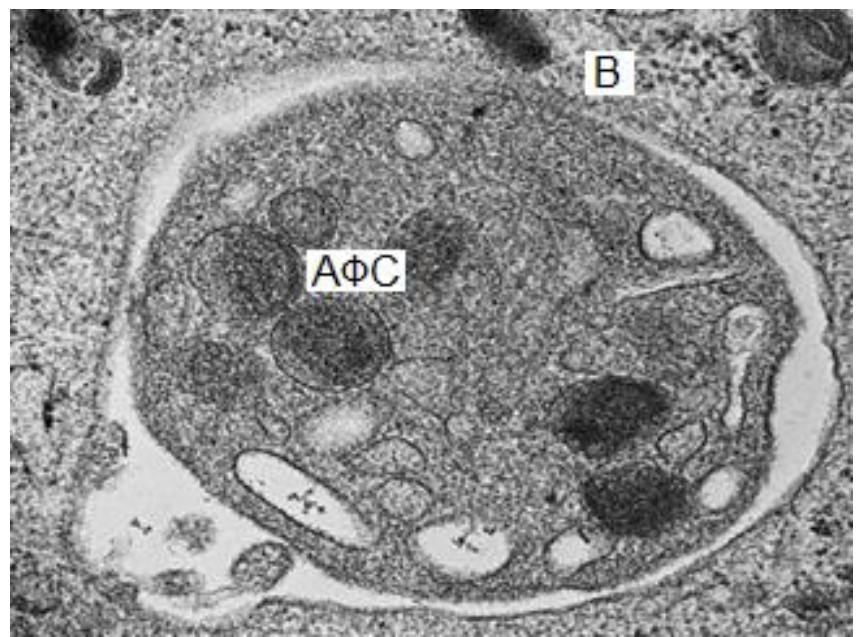

Г.II

Г.І- фрагмент цитоплазмы моноцита с формирующимися аутофагосомами (АФС): Г.ІІ фррагмент цитоплазмы макрофага больных тяжелой астмой с вакуолями содержащими. аутофрагосомы (АФС). Ф - фрормирующаяся фрагофора, АФС - аутофрагосома.

Рис.3. Ультраструктура моноцитов здоровых доноров и больных тяжелой фрормой астмы.

В образцах здоровых доноров выявили классические признаки ультраструктуры моноцитов: ядра бобовидной, подковообразной, иногда дольчатой фрормы с выпуклостями и углублениями. Хроматин слабо конденсирован. В ядре гетерохроматин представлен зёрнами рассеянными ядру и, как правило, в больших количествах залегает под ядерной мембраной. В цитоплазме клеток определялось небольшое количество органелл: редкие округлые светлые митохондрии, немногочисленные удлиненные каналы ГЭР, лизосомы разных размеров с темным и светлым однородным содержимым, слабо развитый комплекс Гольджи, множество свободных рибосом и полисом (рис.3-AІ).

Моноциты образцов больных тяжелой фрормой астмы (рис.3-БІІ), в основном, представлены диффференцирующимися макрофрагами: Форма всей клетки и ядра - неправильная. В ультраструктуре макрофрага характерными элементами являются многочисленные вакуоли и лизосомы с мелкогранулярным содержимым, митохондрии и ЭПР. На поверхности клетки появляются длинные вытянутые отростки и удлиненные ядра с извилистыми неровными краями. Эухроматин в ядре распределяется равномерно, гетерохроматин выявляется по периферии кариолеммы в виде тонкого ободка.

Наряду с возрастанием в тканях числа юных макрофрагов проявлялись ультраструктурные признаки усиления их белоксинтезирующей активности. Цитолемма у некоторых макрофагов формировала короткие утолщенные выросты и инвагинации, участвующие в захвате частиц биоматериала и образовании фрагоцитарных вакуолей. Однако наряду с фрагосомами мы обнаружили фрагофоры и аутофагосомы (рис.3,В) - органеллы характерные для запуска процесса аутофагии в макрофрагах. Во время аутофагии фрагофора (двойная мембра - рис.3, В-вставка) инкапсулируют цитоплазматический материал, такой как дисфункциональные или поврежденные органеллы, белки или апоптотические тельца в фагосомы, образуют так называемые аутофрагосомами (АФС). Затем аутофагосомы сливаются с лизосомами, ферменты которых деградируют цитоплазматический 
материал. В последние десятилетияе аутофрагия стала фундаментальным процессом, связанным не только с тканевым и клеточным гомеостазом, существует все больше доказательств того, что аутофагия может влиять на патогенез и / или прогрессирование многих заболеваний человека [5]. Однако, наряду с канонической аутофагией существует еще один процесc, LAP-LC3-ассоциированная аутофрагия, обеспечивающий клеткам избавление от потенциальных угроз и, тем самым, еe выживание. LAP был описан еще в 2007 году [6]. Это процесс, который инициирует поглощение проникающего патогена плазматической мембраной с образованием одномембранной фагосомы (Ф), после чего она «украшается» молекулами LC3 белком. Помимо бактериальных клеток также происходит распознавание апоптотических, некротических или энтотических [8]. Несмотря на совместное использование некоторых молекулярных механизмов, в настоящее время существует несколько различий, которые диффференцируют LAP от канонической аутофрагии. В частности, два белка Rubicon и Nox2 присутсвуют только при активации LAP, экспрессию которых мы обнаружили в лимфоцитах больных тяжелой фрормой астмы [8].

Мы предполагаем, что в моноцитах больных тяжелой атопической астмой развивается неканоническая аутофагия. Что является предметом дальнейшего изучения, т.к. по данным литературы, дефекты в LAP, а не канонической аутофрагии, могут вызывать СКВ-подобные явления и могут способствовать патогенезу СКВ [7,9]

\section{Литература}

1. Адо А. Д. Патологическая физиология // М.: Триада-Х. 2000. С. 574.

2. Kay A. B. T cell as orchestration of the asthmatic response. // Ciba Found Symp. 1997. V. 206. P. 56-5.

3. Shirai T., Suzuki K., Inui N., Suda T., Chida K., Nakamura H. Thl/Th2 profile in peripheral blood in atopic cough and atopic asthma. // Clin. Exp. Allergy. 2003. V. 33. N. 4. P. 84-89. 4. Мамонтова Т. В. Атопическая бронхиальная астма и устойчивость к апоптозу // Актуальні проблеми сучасної медицини. 2008. Т. 8. № 4. С. 171.

4. Eskelinen E. L., Saftig P. Autophagy: a lysosomal degradation pathway with a central role in health and disease. 2009. P. 664-673. DOI: 10.1016/j.bbamcr.2008.07.014

5. Nagata S., Hanayama R., Kawane K. Autoimmunity and the clearance of dead cells // Cell. 2010. V. 140. P. 619-630.

6. Martinez J., Subbarao Malireddi R. K., Lu Q., Green D. R Molecular characterization of LC3-associated phagocytosis reveals distinct roles for Rubicon, NOX2 and autophagy proteins // Nat Cell Biol. 2015. V. 17. N. 7. P. 893-906.

7. Martinez J., Cunha L. D., Park S., Green D. R. Noncanonical autophagy inhibits the auto-inflammatory, lupus-like response to dying cells // Nature. 2016. V. 5. N. 533(7601). P. 115-119.

8. Skibo Yu. V., Tikhomirova M. V., Abramov S. N., Analysis of the Expression of Key Protein Regulators of Apoptosis and Autophagy in T-Lymphocytes of Patients with Bronchial Asthma // Uchenye zapiski Kazanskogo universiteta-Seriya estestvennye nauki. 2019. V.161. Is.4. P.505-520. 
9. Heckmann B. L., Boada-Romero E., Cunha L. D., Magne J., Green D. R. LC3Associated Phago-cytosis and Inflammation //J Mol Biol. 2017. V. 24. N. 429(23). P. 35613576. DOI: 10.1016/j.jmb.2017.08.012. Epub 2017 Aug 25.

\section{Features of cell death of monocytes in patients with atopic bronchial asthma}

B. R. Ibragimov, Yu. V. Skibo, Z. I. Abramova

Kazan Federal University

18 Kremlin street, 420008 Kazan, Republic of Tatarstan, Russia.

Email: ibragimov94@inbox.ru

To assess the nature of programmed cell death, we used the method of transmission electron microscopy and found significant morphological differences - in patients with severe atopic bronchial asthma, macrophages with signs of autophagy are mainly found.

Keywords: apoptosis, canonical autophagy, Lap-associated phagocytosis, macrophages, atopic bronchial asthma. 